\title{
Restorative design of urban brownfields, an interdisciplinary approach interconnecting nature-based solutions, heritage requalification and human wellbeing. A case study in Rome
}

\author{
Maria Beatrice Andreucci ${ }^{1}$, Luciano Cupelloni ${ }^{1}$, Marco Delli Paoli ${ }^{1}$ and Silvia Coccolo ${ }^{2}$ \\ ${ }^{1}$ Sapienza University of Rome, Rome, Italy \\ ${ }^{2}$ Ecole Polytechnique Fédérale de Lausanne, Lausanne, Switzerland
}

\begin{abstract}
In order to face increasing socio-economic challenges in a climate-change scenario, we should aim at re- designing our built environment, improving resilience and sustainability. Green infrastructure - trees in particular play a critical role in urban heat island mitigation. Outdoor comfort simulations are useful tools to assess microclimate, and the different parameters influencing human energy balance and thermal comfort. The potential of bioclimatic design is illustrated testing the simulation tools Ecotect and CitySim on a dismissed iconic pharmaceutical factory in Rome (Italy), supporting its regenerative project, and thus offering useful insights for evidence-based design of urban post- industrial degraded sites.
\end{abstract}

\section{Introduction}

Urban climate, and urban heat islands in particular, have been widely investigated in the last decades $(\mathrm{Ng}, 2010$; Morris et al., 2016). Studies have been conducted specifically in the Mediterranean zone, one of the most vulnerable to climate change, with UHI intensity varying, according to Santamouris (2007), between $2^{\circ} \mathrm{C}$ and $10^{\circ} \mathrm{C}$. These results are confirmed by analyses carried out in Rome (Salvati et al., 2016), which detected an average UHI intensity between $3^{\circ} \mathrm{C}$ and $4{ }^{\circ} \mathrm{C}$, with a peak intensity of $4.5^{\circ} \mathrm{C}$ in summer.

The main factors that influence human thermal comfort are those that determine heat gain and loss, namely metabolic rate, clothing insulation, air temperature, mean radiant temperature, air speed and relative humidity. Psychological parameters, such as individual expectations, also affect thermal comfort (de Rear and Brager, 1998).

It is a well-established fact that thermal comfort is strongly correlated to outdoor urban environment (Charalampopoulos et al., 2016; Nouri et al., 2017; Saaroni et al., 2018). Michelozzi et al. (2005) and Legambiente (2018) have highlighted the problems and challenges related to thermal discomfort in Roman urban open spaces.

According to Köppen-Geigen classifications (1933), Rome belongs to the "Csa" hot dry summer Mediterranean climate. The exceptional heat waves of summer 2003, when peak temperatures reached record values, had in particular a strong impact on the population in terms of mortality, with a total of 944 excess deaths observed $(+19 \%)$.

There are several design strategies to mitigate the UHI by manipulating the urban energy balance and changing some terms and/or factors: (i) varying the albedo (the ratio of irradiance reflected to the irradiance received by a surface) to reduce net radiation, (ii) improving ventilation affecting human heat load, and (iii) augmenting evaporative and shading potential. Greening, especially tree planting, has a positive effect on the outdoor thermal comfort (Akbari et al., 2001; Picot, 2004), intercepting solar radiation and preventing the underlying surface to absorb shortwave radiation, a process known as shading effect (Bowler et al., 2010).

With the proper implementation of strategies levering on nature-based solutions, particularly trees, it is possible to mitigate the UHI, thanks to the cooling potential given by evapotranspiration and surface temperature reduction through shading (Zürcher and Andreucci, 2017; Samson et al., 2017).

\section{Methods}

\section{Site selection and characteristics}

The project area, approximately 4.5 hectares, is among the most vulnerable in the city of Rome, located close to the Aniene river Natural Reserve, and characterized by the massive presence of industrial settlements.

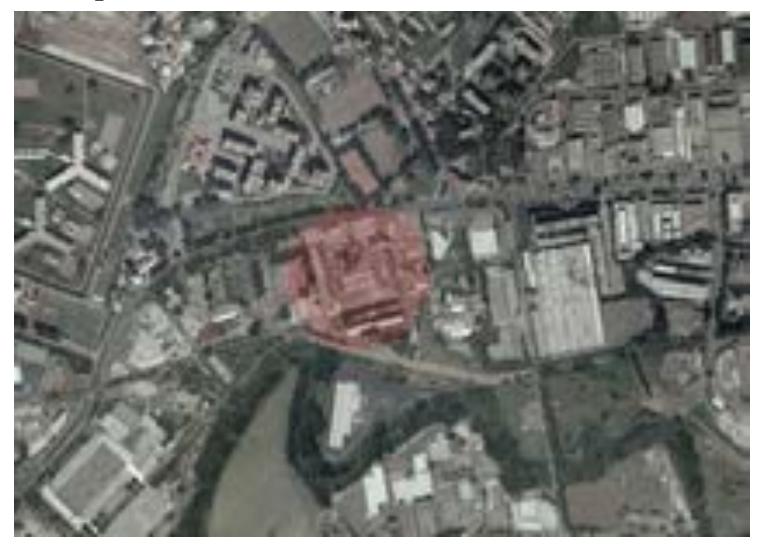

Figure 1: The project area: the "Leo" factory in Rome. Google Earth, 2008.

Among the industrial buildings, the iconic 1950s heritage "Leo" penicillin factory, abandoned since 2003, and certainly an emblematic construction due to its size and the inconvenient and cumbersome presence of processing waste, harmful to the people and the environment. 
Urban expansion determined over time ecological fragmentation and diffused degradation, causing substantial loss of natural capital in a fragile transition ecotone. Moreover, as underlined by the report from 'Medici senza Frontiere' (2018), the area of the Leo Factory in Rome is quite a problematic area, due to impellent social and medical needs.

Over the years, the factory has become the site of violent incidents that have made some areas of the neighborhood inaccessible and unsafe, becoming a home for homeless people and for hospitality's beneficiaries that haven't yet been allocated to residences in the Municipality of Rome. Poor living conditions are evident also in the neighboring areas, hosting blue-collar workers and marginalised people close to the 'Tiburtina Valley', a productive area which still experiences flourishing business activities.

The project provides the restoration of socio-ecological connections achievable through new pedestrian and cycle paths, and a bio-eco-oriented open space design (Figures 2 and 3), ensuring accessibility, safety and comfort to citizens and visitors both in the post- industrial areas, and in the other public space outside the former Leo factory.

Specifically, a homeless shelter for asylum seekers is proposed, integrating the facility with other public services, and thus increasing the social inclusiveness potential of the Tiburtina area. A comprehensive timber construction system is proposed for the new buildings' construction and the multilayered paths reconnecting the site, the City and the Aniene Park.

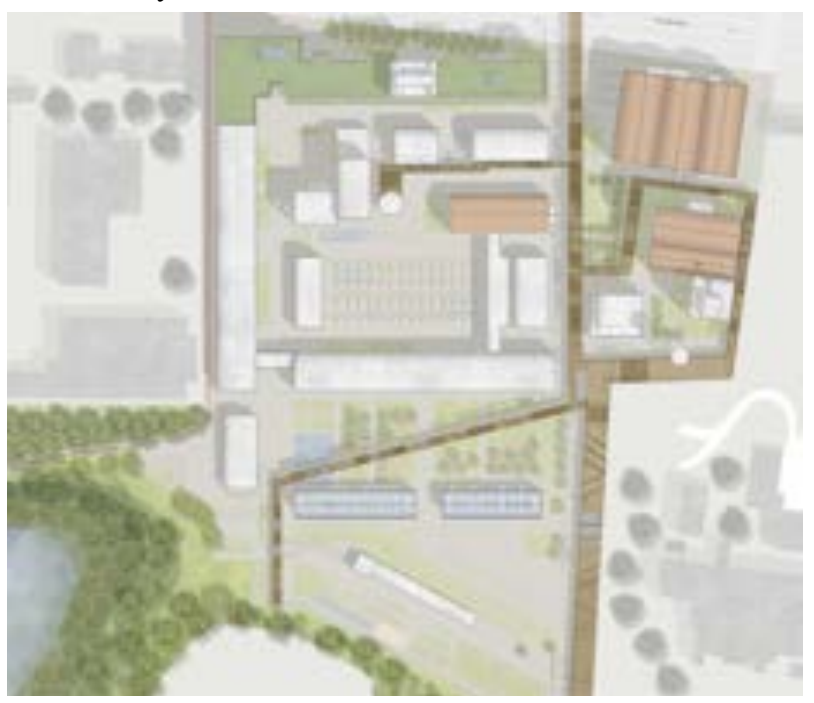

Figure 2: Master Plan of the 'Asylum Tiburtinum'.

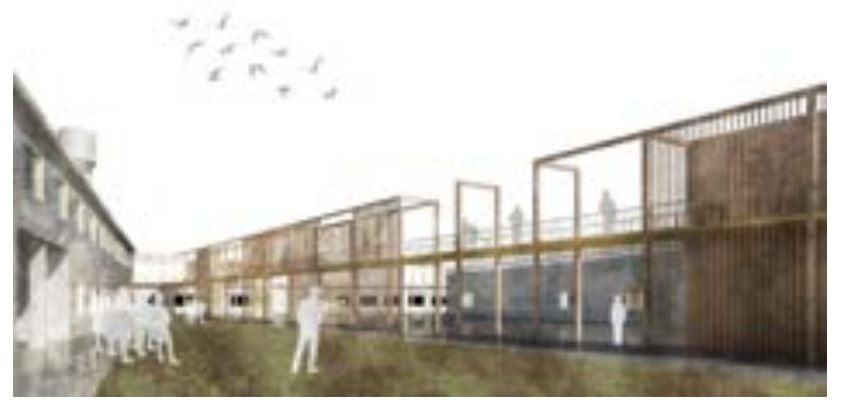

Figure 3: Visualisation of the central public space.

\section{Microclimate data collection and modelling}

The climatic data for the city of Rome are defined by the tool Meteonorm 7.3.0, (2013) providing the hourly data for a typical meteorological year. The meteorological data (air temperature, solar radiation, relative humidity, rainfalls, wind speed and direction) are summarized in Table 1 (Meteonorm, 2013). It should be noted that the summer season in Rome is quite warm, with an average temperature of $27.3^{\circ} \mathrm{C}$ during the month of August.

Table 1: Meteorological data for the city of Rome. Meteonorm, 2013.

\begin{tabular}{|c|c|c|c|c|c|c|}
\hline Month & $\begin{array}{c}\text { Beam } \\
\text { Radia- } \\
\text { tion } \\
\mathbf{W} / \mathbf{m}^{2}\end{array}$ & $\begin{array}{c}\text { Air } \\
\text { Tempe- } \\
\text { rature } \\
{ }^{\mathbf{C}}\end{array}$ & $\begin{array}{c}\text { Wind } \\
\text { Speed } \\
\mathbf{m} / \mathbf{s}\end{array}$ & $\begin{array}{c}\text { Wind } \\
\text { Direc- } \\
\text { tion } \\
\circ\end{array}$ & $\begin{array}{c}\text { Relative } \\
\text { Humi- } \\
\text { dity } \\
\mathbf{\%}\end{array}$ & $\begin{array}{c}\text { Total } \\
\text { Rain- } \\
\text { falls } \\
\mathbf{m m}\end{array}$ \\
\hline Jan. & 82.5 & 8.8 & 0.9 & 136 & 67.2 & 53.6 \\
\hline Feb. & 103.9 & 9.6 & 1.2 & 147 & 63.0 & 41.7 \\
\hline Mar. & 137.9 & 12.6 & 1.4 & 159 & 64.6 & 37.7 \\
\hline Apr. & 157.9 & 15.4 & 1.3 & 174 & 67.0 & 47.8 \\
\hline May & 198.7 & 20.6 & 1.2 & 186 & 61.8 & 36.6 \\
\hline Jun. & 216.1 & 24.2 & 1.4 & 198 & 59.3 & 14.9 \\
\hline Jul. & 261.3 & 27.2 & 1.6 & 202 & 55.2 & 15.3 \\
\hline Aug. & 217.0 & 27.3 & 1.4 & 203 & 58.6 & 27.9 \\
\hline Sep. & 162.1 & 22.3 & 1.2 & 179 & 64.7 & 55.8 \\
\hline Oct. & 125.6 & 18.9 & 0.8 & 184 & 69.8 & 62.7 \\
\hline Nov. & 81.3 & 13.7 & 1.0 & 158 & 71.2 & 93.9 \\
\hline Dec. & 65.8 & 10.0 & 0.9 & 150 & 69.1 & 91.4 \\
\hline
\end{tabular}

Different tools are applied to test the design characteristics of the project site: ECOTECT (Marsh, 2006) to study the sun shadow range; Revit Insight 360 to analyse the solar incident radiation, and the yearly cumulative insolation; and CitySim (Robinson et al., 2009), computing the energy behaviour of trees and grass, in time and space (Coccolo et al., 2018).

The urban energy model, in particular, is defined thanks to the tool CitySim, in order to analyse the outdoor environmental conditions in the selected urban area. Firstly, the geometrical design, available in DXF format, is included in the tool, and all the thermo-physical properties of the urban factory (albedo, conductivity, density, specific heat and thickness of each composite) are determined.

The lack of green open space determines, in proximity of the factory, and in particular during the summer, an elevated impact on the radiative environment, with an evident influence on the urban microclimate, and potentially very harmful effects on the population and the environment. In order to understand specifically the impact of greening on the urban microclimate, as well as on the outdoor thermal comfort of the pedestrians, the evapotranspiration potential from trees and grass is computed, thanks to the Food and Agriculture Organization of the United Nations (1988), Campbell and 
Norman (1998), and Coccolo et al. (2018) evapotranspiration models.

Two simulations are performed: the current situation, and the renovation scenario. In the renovation scenario, the natural landscape in the southern area of the site is improved planting 28 new trees belonging to the flag species of the local riparian forest - Salix alba, Populus alba, Alnus glutinosa, Ulmus minor (Blasi et al., 2010) seven meter tall, and with an average Leaf Area Index (defined as the one-sided green leaf area per unit ground surface area) corresponding to 3 . In order to understand the impact of the green infrastructure renovation on the microclimatic conditions, the ground surface temperature is analysed during the summer season. Subsequently, the impact of greening on the outdoor thermal comfort is computed, thanks to the COMFA* budget - an updated version of the thermal energy model COMfort FormulA (Brown and Gillespie,1986) - based on work by Kenny et al. (2009), able to quantify the energy fluxes exchanged by the pedestrians with the outdoor environment (metabolic heat, radiation absorbed, long-wave radiation emitted, convective heat losses, and evaporation). A pedestrian is virtually located inside the "Leo" Factory, and his thermal comfort, i.e. the energy exchanged between the human body and the outdoor environment, is computed as follows (Vanos et al., 2017):

$$
E B=M+R_{a b s}-C-E-L_{\text {emit }}
$$

where: $E B$ is the heath balance, $M$ is the metabolic heat generated by a person, $R_{a b s}$ is the radiation absorbed, $C$ represents the convective heat losses, $E$ is the evaporation, and $L_{\text {emit }}$ is the longwave radiation emitted by a person. All values are expressed in $\mathrm{W} \mathrm{m}^{-2}$. The total "comfortable hours" are computed during a typical meteorological year, by including the physical and geometrical properties of the urban space under investigation. Table 2 summarizes the COMFA* thermal scale, i.e. the energy budget values, and the corresponding predicted thermal sensations. The neutral thermal sensation corresponds to -50 to +50 $\mathrm{W} \mathrm{m}^{-2}$, while a thermal sensation can be considered acceptable when the values are in the range -120 and $+120 \mathrm{~W} \mathrm{~m}^{-2}$, which correspond respectively to a "slightly cool" and a "slightly warm" thermal sensation. For detailed data on the pedestrian model please refer also to Coccolo et al. 2018b.

Table 2: Thermal sensation as a function of the COMFA* budget. Kenny et al., 2009a.

\begin{tabular}{|c|c|}
\hline Thermal sensation & COMFA ${ }^{*}$ budget $\left(\mathbf{W ~ m}^{-\mathbf{2}}\right)$ \\
\hline Cold & $\leq-201$ \\
\hline Cool & -200 to -121 \\
\hline Slightly Cool & -120 to -51 \\
\hline Neutral & -50 to +50 \\
\hline Slightly warm & +51 to +120 \\
\hline Warm & +121 to +200 \\
\hline Hot & $\geq 201$ \\
\hline
\end{tabular}

The ground covering is subdivided into three main typologies: water, vegetation and artificial ground covering.
All the physical properties of the material composing the ground are summarized in Table 3.

Table 3: Properties of the ground covering.

Data adapted from Erell et al., 2011.

\begin{tabular}{|c|c|c|c|}
\hline $\begin{array}{c}\text { Material } \\
\text { Name }\end{array}$ & $\begin{array}{c}\text { Thermal } \\
\text { Conductivity } \\
\mathbf{W} \cdot \mathbf{m}^{-1} \mathbf{K}\end{array}$ & $\begin{array}{c}\text { Density } \\
\mathbf{~ K g} \cdot \mathbf{m}^{-\mathbf{3}}\end{array}$ & $\begin{array}{c}\text { Specific Heat } \\
\mathbf{J} \cdot \mathbf{k g}^{-\mathbf{1}} \mathbf{K}^{-\mathbf{1}}\end{array}$ \\
\hline Concrete & 2.1 & 2,400 & 849 \\
\hline Concrete tiles & 1.5 & 2,100 & 1,000 \\
\hline Gravel & 2 & 2,000 & 1,051 \\
\hline Soil & 1.5 & 2.098 & 1.500 \\
\hline
\end{tabular}

\section{Results}

\section{Shadow range generation}

ECOTECT analyses (Figures 4 and 5) of the ex-ante status of the former Leo factory highlight different critical situations due to the geometry of the site, and in particular to the different volumes located within the complex producing a constant winter shadowing of specific areas. The buildings along the main road, via Tiburtina, provide a wide solar absorption surface, disadvantageous in the summertime (Figure 4), and favourable during the winter (Figure 5). The other constructions of the industrial complex are arranged in a grid defined by the internal informal road network, also increasing the shadowed areas, both in open spaces and buildings.

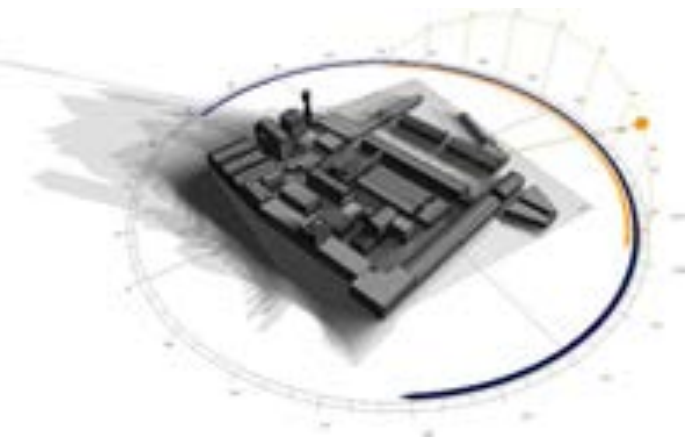

Figure 4: Shadow range, June $21^{\text {st }}, 10$ a.m.- 4 p.m.

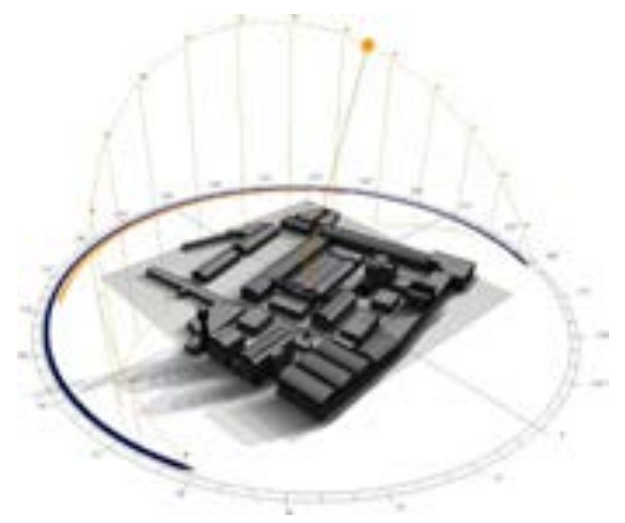

Figure 5: Shadow range, Dec. $21^{\text {st }}, 10$ a.m.- 4 p.m.

The project proposes a photovoltaic system on the roof to produce electricity for the overall self-sufficiency of the complex, and whose elements are integrated into the south facade cladding panels. 
The elevated path created by the project consists of a modular structure of lamella wood able to screen the south front during the summer, and to allow for the useful solar gain in winter. Moreover, the demolition of selected buildings and the appropriate clearing of other existing ones optimize the natural lighting of interiors, guaranteeing good levels of comfort, especially in residential areas. Where the above solutions are not possible, new glasses and windows with longer spans have been positioned improving the internal illumination.

\section{Solar irradiation profiles}

Energy simulations provide the values of incident solar radiation (Figures 6 and 7) and cumulative insolation (Figures 8 and 9) of the buildings' envelope.

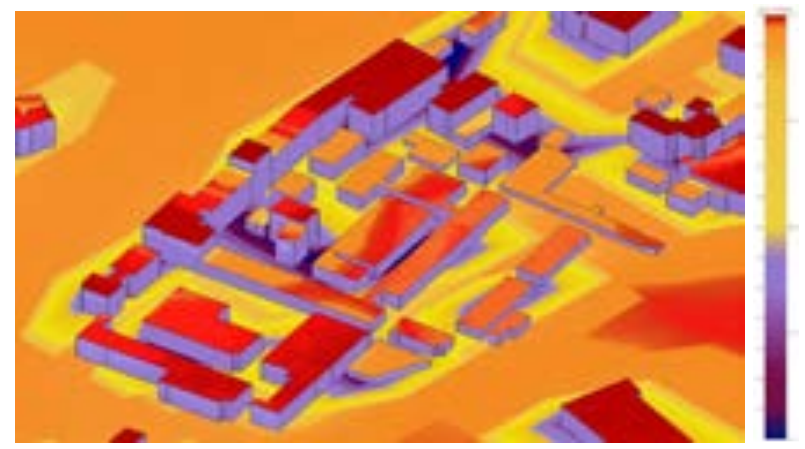

Figure 6: Incident solar radiation analyses. Southwest view.

In the model's view from the southwest (Figure 6), the open spaces receive a low insolation on average, and sometimes equal to 0 .

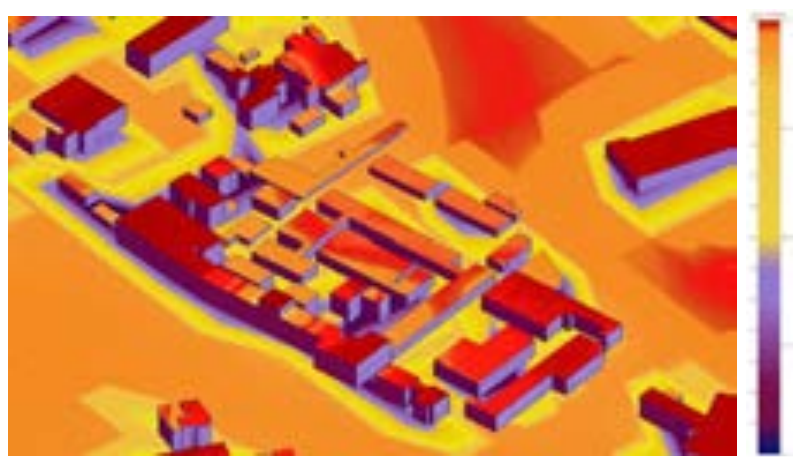

Figure 7: Incident solar radiation analyses. Northwest view.

The model's northwest view (Figure 7) shows the complete lack of natural light along the entire north front, while the roofs enjoy, on average, a higher degree of insolation. The cumulative insolation analyses (Figures 8 and 9) of the buildings' envelope show that the average value during winter (Figure 8 ) is around $0.5 \mathrm{kWh} / \mathrm{m}^{2}$ per day, for the vertical envelope (with a minimum value of 0 ), and about $1 \mathrm{kWh} / \mathrm{m}^{2}$ per day for the roof. During the summer (Figure 9) the values reach around $2.5 \mathrm{kWh} / \mathrm{m}^{2}$ per day for the vertical walls, and peaks up to $5 \mathrm{kWh} / \mathrm{m}^{2}$ per day for the roof and the surfaces most critically exposed to direct solar radiation.

These data have in particular been taken into account when considering the shading requirements of the buildings and assessing the best areas to place photovoltaic for maximum collection over any period throughout the year.

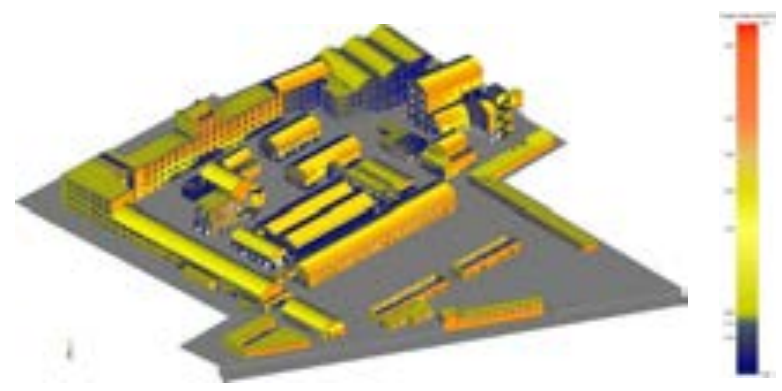

Figure 8: Yearly cumulative insolation analyses. Winter.

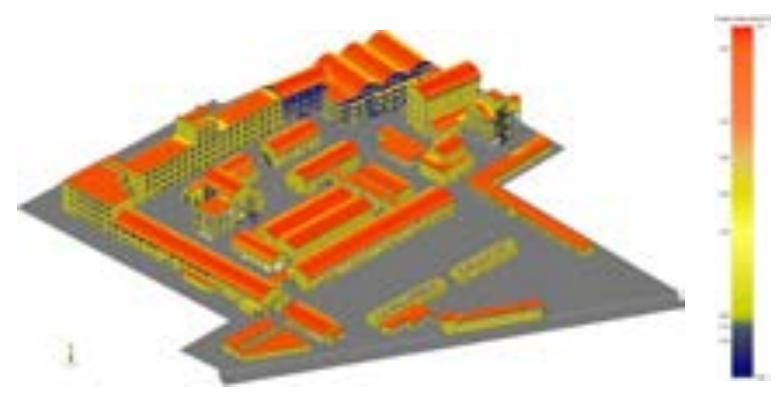

Figure 9: Yearly cumulative insolation analyses. Summer.

\section{Urban energy model}

This study underlines the impact of greening on the urban surface thermal balance providing a direct indication of the magnitude of the UHI within the city borders. More simulations are performed focusing on the impact of the landscape renovation project on the yearly and monthly surface temperature of the site, as well as on the outdoor thermal comfort. Figures 10 and 11 show the yearly average surface temperature of the site, before and after the proposed intervention. The southern area, covered by the new vegetation, presents on a yearly basis an important surface temperature reduction, dropping from $24.9^{\circ} \mathrm{C}$ to $23.6^{\circ} \mathrm{C}$. The cooling phenomenon is more evident during the summer season, when newly implemented greening is expected to determine significant reductions of the extreme warm and hot events.

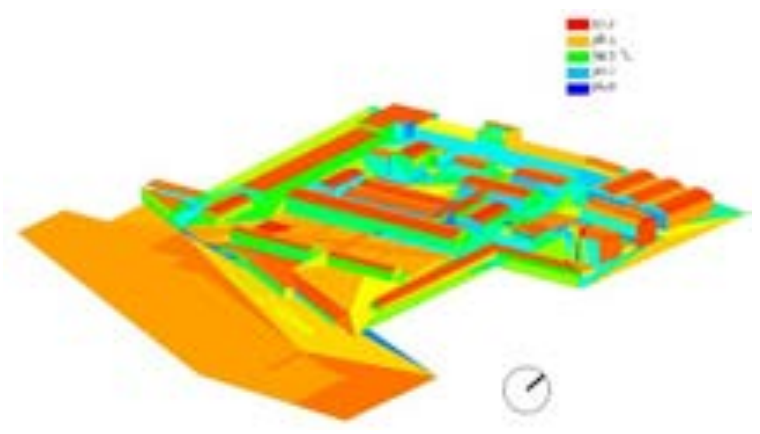

Figure 10: Annual surface temperature of the Leo factory. Existing design. 


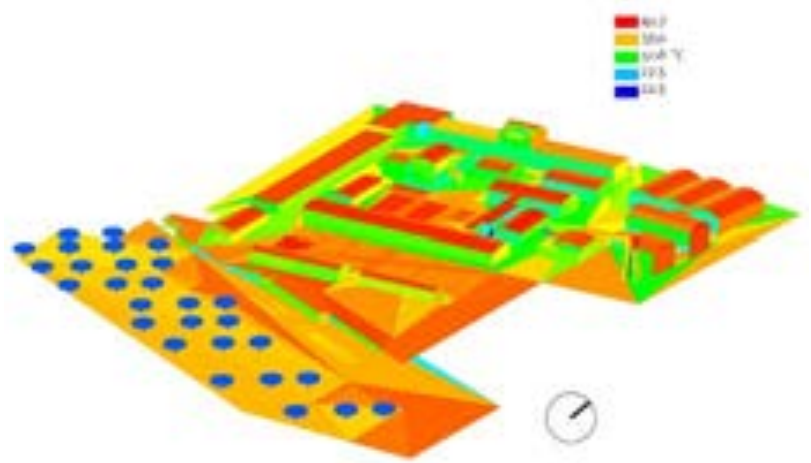

Figure 11: Annual surface temperature of the Leo factory. Renovated design.

In the project site, the total hours characterized by a thermal sensation tolerable for a standing relaxing outdoor activity (COMFA* budget between -120 to $+120 \mathrm{~W} \mathrm{~m}^{-2}$ ), corresponds to 6,154 in the ex-ante scenario, and to 6,462 considering the beneficial effects of the proposed renovation.

The positive effects of greening are more evident during the summer season, when the outdoor thermal conditions are mitigated thanks to the shading provided by trees, and the cooling provided by the evapotranspiration (Figure 12).

Indeed, during the summer season the comfortable hours correspond to 1,616 in the existing situation, rising up to 1,708 thanks to the renovation. This implies that approximately 1 additional hour per day is attributable to the climate-adaptive environmental design. Additionally, is it important to note that a new urban forest (Zürcher and Andreucci, 2017) will impact not just the large area inside the former Leo factory, but it will also benefit the surroundings and the neighbouring inhabitants (Cohen et al., 2012; Feyisa et al., 2014; Skoulika et al., 2014; Zhang et al., 2017).

\section{Conclusion}

Dismissed urban areas, urban brownfield, are often considered as "empty" spaces within the city, secluded spaces for poor and marginalised people (Camilli and Zandonini, 2018). In parallel, we are witnessing a growing interest in the requalification of dismissed areas, urban brownfield and grey-fields for the major role they can play in climate adaptation (Andreucci, 2017; Mahzouni, 2018), bringing new value into poor- quality environments and creating new sets of behaviour in declining urban communities.

The concept of "Design with Climate" (Olgyay, 1962; Givoni, 1969) has rapidly evolved in the last decades, and identifies a climate sensitive approach to the planning and design of outdoor spaces (Bowler et al., 2010). Within this framework, outdoor thermal comfort models provide critical tools for evaluating the suitability of spaces for various nature-based solutions and environmental design strategies.

The case study of the former penicillin factory Leo in Rome has been selected for its peculiar features, being an abandoned post-industrial site in a densely populated semi-central area of the City, characterized by the valuable presence of the Aniene River Natural Reserve and flourishing production activities, within a context of strong environmental degradation and dismissed building constructions.

The simulations performed with the different tools confirm the positive impact of the proposed bioclimatic renovation: in particular, planting 28 deciduous broadleaf trees in the semi-natural open space located in proximity of the former pharmaceutical factory increases the outdoor thermal comfort up to one hour per day during the summer season.

Additionally, thanks to the climate-adaptive landscape design, the average surface temperature of the site is reduced, decreasing the urban heat island effect in this critical district of the city of Rome.

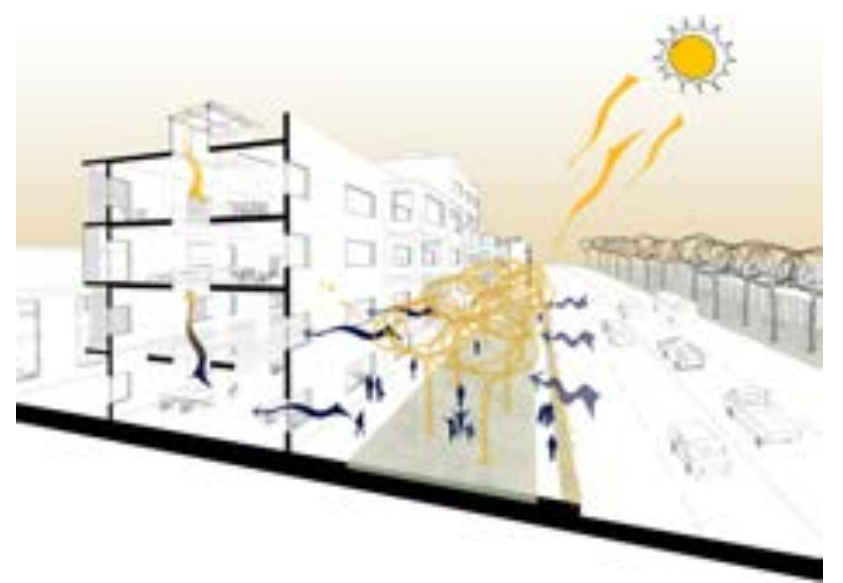

Figure 12: Visualisation of the thermal comfort effects in summer provided by renovated open space design. Northern areas.

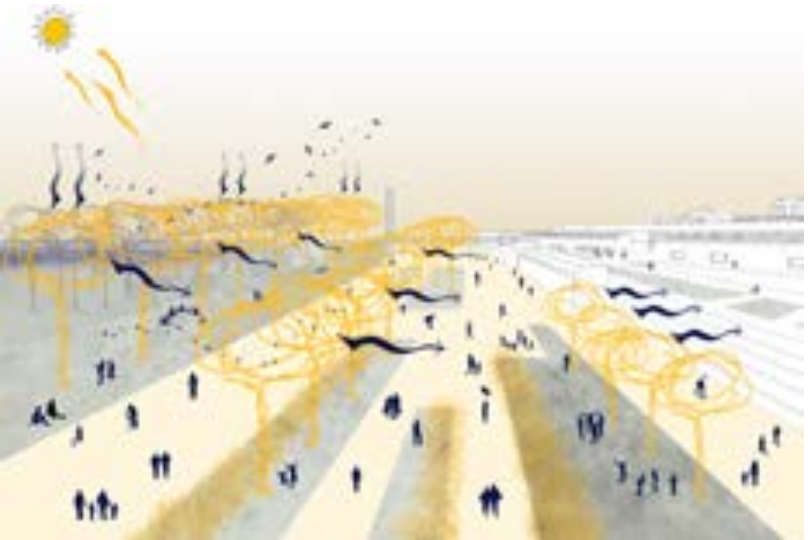

Figure 13: Visualisation of the thermal comfort effects in summer provided by renovated open space design. Southern areas.

This study represents a first step in the analysis of the micrometeorological impacts of greening the urban brownfields in Rome, and further studies are required, aiming to create a comprehensive map of the City, focusing on their potential in mitigating the urban heat island effect, and improving overall health and wellbeing of the urbanites. 


\section{References}

Akbari, H., Pomerantz, M. and H. Taha (2001). Cool surfaces and shade trees to reduce energy use and improve air quality in urban areas. Sol. Energy 70, 295-310.

Andreucci, M.B. (2017). Green Infrastructure e tecnologie di fitorisanamento dei suoli periurbani. Esperienze di riqualificazione tecnologica ambientale di aree industriali dismesse. Urbanistica Informazioni 271, 22-24.

Bowler, D.E., Buyung-Ali, L., Knight, T.M. and A.S. Pullin (2010). How effective is 'greening' of urban areas in reducing human exposure to ground level ozone concentrations, UV exposure and the 'urban heat island effect'? (Systematic Review No. 41).

Brown, R.D. and T.J. Gillespie (1986). Estimating outdoor thermal comfort using a cylindrical radiation thermometer and an energy budget model. Int. J. Biometeorol. 30(1), 43-52.

Camilli, E., Zandonini, G. (2018). Nell'ex fabbrica di penicillina, un ghetto di Roma. Available on-line: https://openmigration.org/analisi/nellex-fabbrica-dipenicillina-il-grande-ghetto-di-roma/ (accessed on 10 November 2018).

Campbell, G.S., Norman, J.M. (1998). An Introduction to Environmental Biophysics. Springer. New York, New York, NY (USA).

Charalampopoulos, I., Tsiros, I., Chronopoulou-Sereli, A. and A. Matzarakis (2016). A methodology for the evaluation of the human-biolcimatic performance of open spaces. Theor. Appl. Climatol. 128, 811-820.

Coccolo, S., Pearlmutter, D., Kaempf, J. and J.-L. Scartezzini (2018b). Thermal Comfort Maps to estimate the impact of urban greening on the outdoor human comfort. Urban For. Urban Green. 35, 91105.

de Dear, R. and G. Brager (1998). Developing an adaptive model of thermal comfort and preference. ASHRAE Transactions 104(1), 145-67.

Erell, E., Pearlmutter, D., Williamson, T. (2011). Urban microclimate. Designing the space between buildings. Earthscan. New York, New York, NY (USA).

Food and Agriculture Organization of the United Nations (1988). Crop evapotranspiration - Guidelines for computing crop water requirements. Irrigation and drainage paper No. 56.

Feyisa, G.L., Dons, K. and H. Meilby (2014). Efficiency of parks in mitigating urban heat island effect: An example from Addis Ababa. Landsc. Urban Plan. 123, 87-95.

Kenny, N., Warland, J.S., Brown, R.D. and T.G. Gillespie (2009). Part A: Assessing the performance of the
COMFA outdoor thermal comfort model on subjects performing physical activity. Int. J. Biometeorol. 53, 415-28.

Givoni, B. (1969). Man, Climate and Architecture. Applied Science Publishers Ltd.. London (UK).

Legambiente (2018). Le citta italiane alla sfida del clima.

Marsh, A.J. (2006). ECOTECT, Square One Research, Software V.5.5.

Mahzouni, A. (2018). Urban brownfield redevelopment and energy transition pathways: A review of planning policies and practices in Freiburg. $J$. Clean. Prod. 195, 1476-1486.

Medici Senza Frontiere (2018). Insediamenti informali marginalità sociale, ostacoli all'accesso alle cure e ai beni essenziali per migranti e rifugiati.

Meteonorm (2013). Meteonorm: http://meteonorm.com/.

Michelozzi P., de' Donato, F., Bisanti, L., Russo, A., Cadum, E., De Maria, M., D’Ovidio, M., Costa, G., Perucci, C.A. (2005). Heat Waves in Italy: Cause Specific Mortality and the Role of Educational Level and Socio-Economic Conditions. In Kirch W., Bertollini R., Menne B. Extreme Weather Events and Public Health Responses. Springer. Berlin, Heidelberg (D).

Morris, K.I., Chan, A., Salleh, S.A., Ooi, M.C., Oozeer, M.Y. and Y.A. Abakr (2016). Numerical study on the urbanization of Putrajaya and its interaction with the local climate, over a decade. Urban Climate 16, 1-24.

$\mathrm{Ng}, \mathrm{E}$. (edited by) (2010). Designing high-density cities for social and environmental sustainability. Earthscan. London (UK).

Nouri, A.S. and J.P. Costa (2017). Addressing thermophysiological thresholds and psychological aspects during hot and dry Mediterranean summers through public space design: The case of Rossio. Build. Environ. 118, 67-90.

Olgyay, V. (1962). Design with climate. Princeton University Press. Princeton, NJ (USA).

Picot, X. (2004). Thermal comfort in urban spaces: Impact of vegetation growth: Case study: Piazza della Scienza, Milan, Italy. Energy Build. 36, 329334.

Robinson, R, Haldi, F., Kämpf, J., Leroux, P., Perez, D., Rasheed, A. \& Wilke, U. (2009). CitySim: comprehensive micro-simulation of resource flows for sustainable urban planning. Proceedings Eleventh International IBPSA Conference. Glasgow, Scotland, July 27-30, 2009.

Salvati, A., Coch, H. and C. Cecere (2016). Urban Heat Island Prediction in the Mediterranean Context: an evaluation of the urban weather generator model, $A C E$ Archit. City Environ. = Arquit. Ciudad Y Entorno 11, 135-156. 
Santamouris, M. (2007). Heat Island Research in Europe: The State of the Art. Adv. Build. Energy Res. 1, 123-150.

Saaroni, H., Amorim, J.H., Hiemstra, J.A. and D. Pearlmutter (2018). Urban Green Infrastructure as a tool for urban heat mitigation: Survey of research methodologies and findings across different climatic regions. Urban Clim. 24, 94-110.

Skoulika, F., Santamouris, M., Kolokotsa, D. and N. Boemi (2014). On the thermal characteristics and the mitigation potential of a medium size urban park in Athens, Greece. Landsc. Urban Plan. 123, 73-86.

Vanos, J.K., Herdt, A.J. and M.R. Lochbaum (2017). Effects of physical activity and shade on the heat balance and thermal perceptions of children in a playground microclimate. Build. Environ. 126, 119131.

Zhang, Y., Murray, A.T. and B.L. Turner (2017). II. Optimizing green space locations to reduce daytime and nighttime urban heat island effects in Phoenix, Arizona. Landsc. Urban Plan. 165, 162-171.

Zürcher, N., Andreucci, M.B. (2017). Growing the Urban Forest: Our Practitioners ${ }^{\text {ee }}$ Perspective. In Pearlmutter, D., Calfapietra, C., Samson, R., O'Brien, L., Krajter Ostoić, S., Sanesi, G., Alonso del Amo, R. The Urban Forest. Cultivating Green Infrastructure for People and the Environment. Springer International Publishing AG, Future Cities 7, Cham (D). 